\title{
Assessing the impact of the EQIP High Tunnel Initiative
}

\author{
Analena B. Bruce ${ }^{a *}$ and James R. Farmer ${ }^{b}$ \\ Indiana University \\ Elizabeth T. Maynard ${ }^{\mathrm{c}}$ \\ Purdue University \\ Julia C. D. Valliant ${ }^{\mathrm{d}}$ \\ Indiana University
}

Submitted March 14, 2017 / Revised May 22 and May 25, 2017 / Accepted May 25, 2017 /

Published online August 25, 2017

Citation: Bruce, A. B., Farmer, J. R., Maynard, E. T., \& Valliant, J. C. D. (2017). Assessing the impact of the EQIP High Tunnel Initiative. Journal of Agriculture, Food Systems, and Community Development, 7(3), 159-180. http://dx.doi.org/10.5304/jafscd.2017.073.012

Copyright (C) 2017 by New Leaf Associates, Inc.

\section{Abstract \\ This study evaluated the U.S. Department of Agriculture Natural Resources Conservation Service (USDA NRCS) Seasonal High Tunnel Initiative, or HTI, that the USDA expects to strengthen local and regional food production by increasing the availability of fresh, locally grown food. Goals of the HTI include improved plant}

a * Corresponding author: Analena B. Bruce, Postdoctoral Research Fellow, Department of Recreation, Park, and Tourism Studies, School of Public Health-Bloomington, Indiana University; 521 North Park Avenue; Bloomington, Indiana 47405 USA; anabruce@indiana.edu

b James R. Farmer, Assistant Professor, Department of Recreation, Park, and Tourism Studies, School of Public Health-Bloomington, Indiana University; 521 North Park Avenue; Bloomington, Indiana 47405 USA; jafarmer@indiana.edu

${ }^{c}$ Elizabeth T. Maynard, Extension Specialist and Clinical Engagement Assistant Professor, Department of Horticulture and Landscape Architecture, Purdue University; P.O. Box 1759; Valparaiso, Indiana 46384-1759 USA; emaynard@purdue.edu and soil quality, reduced nutrient and pesticide runoff, and increased availability of fresh vegetables and fruits for local food markets. This study explored the farm-level impacts of production via high tunnels among Indiana farmers relying on the infrastructure. We identify characteristics of farmers who have obtained high tunnels through the cost-share program, to better understand the types of farm enterprises that are using the HTI to date and the effects that high tunnel implementation may have on their farms' economic success and contributions to locally sourced food systems. Overall, results indicate that high tunnel users are able to extend the growing season, improve their

\footnotetext{
d Julia C. D. Valliant, Postdoctoral Research Fellow, The Ostrom Workshop in Political Theory and Policy Analysis, Indiana University; 521 North Park Avenue; Bloomington, Indiana 47405 USA; jdv@indiana.edu
}

\section{Disclosure}

This work was supported by the Indiana State Department of Agriculture Specialty Crops Block Grant program under Grant \# SCBG-15-002. The funder played no role in the study. 
farm's economic stability, and increase the quality and yield of their crops. Our survey also finds that those farmers who have self-funded all or a portion of their high tunnels report greater increases in their farm's economic stability from investing in high tunnels than farmers relying on the NRCS funds for their high tunnels.

\section{Keywords}

High Tunnels; Hoophouses; High Tunnel Initiative; Environmental Quality Incentives Program; Local Food Systems; Small Farms; Beginning Farmers; Diversified Farms; Specialty Crops; Know Your Farmer, Know Your Food Initiative

\section{Introduction}

High tunnels, or hoophouses, are plastic-covered, greenhouse-like structures for growing plants that are typically built directly over the soil to control the growing environment inside (Carey, Jett, Lamont, Nennich, Orzolek, \& Williams, 2009). The low-cost structures are heated by passive solar energy and create favorable growing conditions for plants by protecting them from wind, rain, birds, and temperature extremes (Blomgren \& Frisch, 2007; Conner, Montri, Montri, \& Hamm, 2009). Growers can extend the growing season with a high tunnel, leading to earlier, later, and more frequent harvests, thereby producing more fresh produce year-round (Lamont, 2009). Increasing the availability of fresh produce, both in terms of adequate volume during the growing season, and supply during the fall and winter months in colder climates, can address a significant barrier to the further development of community food systems that are limited by low supply during the colder months (Martinez, 2010).

High tunnels may be particularly well suited to small-scale, diversified farms that sell their products into local food systems (Cole, n.d.). Research trials have demonstrated that the use of high tunnels makes it possible for farmers to increase the quality and yield of specialty crops, and to reduce the risk of weather-related crop damage and loss (Belasco, Galinato, Marsh, Miles, \& Wallace, 2013; Knewtson, Carey, \& Kirkham, 2010; Lamont, 2009). By extending their growing season, small farms can capture more revenue and retain their customer base for more months of the year (Martinez, 2010; Matts, Conner, Fisher, Tyler, \& Hamm, 2015). Because they are relatively inexpensive investments that facilitate the intensification of production on small plots of land, high tunnels also offer opportunities for beginning and low-income farmers, and those with a small land base (Conner, Waldman, Montri, Hamm, \& Biernbaum, 2010; Waldman, Conner, Biernbaum, Hamm, \& Montri, 2012). In addition, high tunnels work particularly well for urban-agriculture initiatives because they help producers maximize production in small spaces (Broadway, 2009; Colasanti \& Hamm, 2010; Huff, 2015).

The Seasonal High Tunnel Initiative (HTI) was piloted in 2009 as part of the Know Your Farmer, Know Your Food initiative, which brings together staff from across the USDA to coordinate, share resources, and publicize USDA efforts related to local and regional food systems (Farm News, 2009; USDA, n.d.; USDA NRCS, 2011). Broad goals of the initiative are to support diversified farmers and ranchers, as well as businesses involved in regional food networks, to strengthen the connection between farmers and consumers to reinvigorate rural economies, promote job growth, and increase access to healthy food in America (USDA, n.d.). Thus, from its inception, the HTI was aimed at small-scale, diversified farms that sell directly to consumers through local food systems. The HTI is funded through the Natural Resources Conservation Service's (NRCS) Environmental Quality Incentives Program (EQIP) and offers a cost-share incentive of up to $90 \%$ to farmers interested in constructing a new high tunnel. The NRCS's goals for the HTI include (1) improved plant and soil quality, (2) reduced off-site movement of nutrients and pesticides, (3) improved air quality through reduced transportation from farm to market, and (4) reduced energy use through local consumption (USDA NRCS, 2015). Farmers are investing in high tunnels to improve the viability of their farms through increased and extended productivity, diversified growing systems, and reduced risk of crop damage and loss (Belasco et al., 2013).

This exploratory study provides an analysis of the benefits of growing with high tunnels in general and the effects of the cost-share incentive provided 
by EQIP for use by policy-makers, key stakeholders, and farmers. We identify the characteristics of the farmers who have obtained high tunnels through the cost-share program to better understand the types of farm enterprises that are have used the EQIP to date, and the effects that implementing high tunnels may have on farms' economic success and contributions to locally sourced food systems. Through a survey of farmers using high tunnels in the state of Indiana, we address the following questions:

1. What is the overall impact of using high tunnels in terms of crop yields, crop quality, farm profit, and farmers' quality of life?

2. Do farmers who obtained their high tunnels with support from EQIP differ from those who purchased some or all of their tunnels without support from the EQIP program?

To understand any differences among high tunnel users, we differentiate between those who only have EQIP-funded high tunnels and those who have self-funded one or more of their farm's high tunnels. Analyzing the outcomes of the first five years of the program, this study is the first to provide an understanding of the effects of the HTI from a whole-farm perspective.

\section{Literature Review}

Increasing the adoption of season-extension technology is important for addressing a key barrier in the supply chain to developing more robust local and regional food systems in the many parts of the U.S. with a limited growing season (Conner et al., 2009; Mount, 2012). According to former USDA Deputy Secretary Kathleen Merrigan, "high tunnels create favorable conditions enabling farmers to grow vegetables, berries, and other specialty crops in climates and at times of the year in which it would otherwise be impossible...Farmers who sell their high tunnel produce locally benefit from the extra income, and the community benefits from the availability of fresh, locally grown food" (USDA NRCS, 2011, para. 1). Consumers at three Michigan farmers markets indicated that they were willing to pay a price premium for early- or lateseason salad greens, spinach, and tomatoes; for example, they were willing to pay up to US\$3.00 extra per head of lettuce in the winter season (Conner et al., 2009). A policy report identified high tunnels as a critical infrastructure gap for increasing the distribution of specialty crops in Indiana (Meter, 2012).

Growing in high tunnels also offers the potential for improving the productivity and viability of the small-scale, diversified farms that produce food for local food systems. An informal survey of state extension vegetable specialists indicated that the majority of high tunnel users in the U.S. are beginning farmers operating small-scale, diversified, direct-market operations (Carey et al., 2009). While many benefits of using high tunnels have been identified in research trials, there has not been an adequate study of farmers' lived experiences of integrating high tunnel production into their existing farm systems. A small case study in Michigan found mixed results in terms of farmers' success in increasing their farm's profitability or meeting management goals (Conner et al., 2010; Waldman et al., 2012). In terms of improving profitability and quality of life for farmers, high tunnels were not always used to their full potential (Conner et al., 2010; Waldman et al., 2012). A systematic assessment of the economic impacts, seasonextension potential, and other production benefits at the farm level is needed to fill this gap.

The HTI is designed to provide a streamlined application process and enhanced flexibility to better serve small-scale operations and diversified farm systems (USDA NRCS, 2015). The criteria for HTI cost share eligibility for Indiana farmers is based on the ranking system for the Indiana NRCS specialty-crop program, which ranks each applicant based on their property's conservation activities and their farm's needs (USDA NRCS, 2015). Cost share recipients are required to grow crops directly in the soil in their tunnel (thus aquaponic or greenhouse systems are not allowed), and they must plan supportive conservation practices to address environmental concerns associated with the installation and use of high tunnel systems such as erosion, irrigation, and runoff (USDA NRCS, 2015).

The cost of high tunnel infrastructure varies depending on the size of the tunnel chosen, features and material components selected (basic and 
upgraded), and construction costs. The average high tunnel costs approximately US $\$ 3.25$ per square foot (0.09 square meter), or US $\$ 7,000$ for a 2,160 square foot $\left(201 \mathrm{~m}^{2}\right)$ tunnel (Huff, 2015). However, costs vary by region, with additional reinforcements such as higher gauge hoops and plastic and heavier steel required in northern and eastern regions to withstand harsh winters adding to the overall cost (Huff, 2015). The plastic covering of a high tunnel has an average four to five year lifespan before the plastic must be replaced (Huff, 2015). The Indiana NRCS cost-share funds US $\$ 3.85$ per square foot, with a maximum payment cap of US $\$ 8,385$ (USDA NRCS, 2015).

The HTI is part of a suite of programs and incentives designed to meet the needs of populations of farmers who are deemed historically underserved, defined by the USDA as groups that "have not participated in or that in the past have received limited benefits from USDA programs" (USDA NRCS, 2015). The following groups are included in this category: (1) socially disadvantaged farmers and ranchers, (2) beginning farmers and ranchers (defined as those farming fewer than 10 years), and (3) limited-resource farmers and ranchers. For instance, farmers in these categories are eligible for higher cost-share rates of up to $90 \%$ and are placed in high-priority funding pools. According to the National Sustainable Agriculture Coalition (NSAC), its analysis of USDA data indicates that the HTI has been strongly utilized by beginning farmers, who made up $51 \%$ of program contracts in 2013. Historically underserved producers (in all categories combined) accounted for over $70 \%$ of HTI contract holders in 2013 , while representing just $26 \%$ of participants in EQIP programs in general (NSAC, 2014a, 2014b).

To our knowledge, the only research to date on the HTI is a study that analyzed the nationwide distribution of NRCS-funded high tunnels in relation to county-level biophysical, market, and sociodemographic data, to understand which factors influence the adoption of high tunnels through the HTI (Foust-Meyer \& O'Rourke, 2015). This study found that farmers' geographic location was most correlated with the incidence of NRCS-funded high tunnels. Not surprisingly, farmers located in higher latitudes were more likely to have purchased a high tunnel through the HTI, where farmers most benefit from technologies to extend the growing season. In addition, farmers' proximity to urban areas with higher median household income was related to their participation in the HTI, and female farm operators were proportionately more likely to obtain high tunnels through the HTI. Finally, farmers in or near metropolitan counties with robust local food systems (high direct-toconsumer sales) were most likely to adopt high tunnels through the HTI (Foust-Meyer \& O'Rourke, 2015). Our study assesses the farm-level impacts and benefits of using high tunnels and determines whether those impacts differ for farmers who purchased their own tunnels compared to those who obtained their tunnels through the EQIP program.

\section{Methods}

This exploratory survey examines the outcomes of participation in NRCS's EQIP HTI and also compares those farms with only EQIP-funded high tunnels to those whose high tunnels are all or in part self-funded. We build on earlier case studies of high tunnel users through a quantitative-focused survey that was mailed to farmers across Indiana, USA (Waldman et al., 2012).

\section{Study Site}

While Indiana is known for its commodity agricultural products like corn, soybeans, wheat, pork, and poultry, the state also has specialty crop producers distributing through local food system venues (Meter, 2012). Specialty crops are defined as "fruits and vegetables, tree nuts, dried fruits, horticulture, and nursery crops, including floriculture" (USDA Agricultural Marketing Service, n.d.). In 2012, 2,935 specialty crop farms were operating in Indiana (USDA NASS, 2015), a slight increase from 2,925 in 2007 (USDA NASS, 2007). The Indiana division of the USDA NRCS began administering the EQIP HTI cost-share program to Indiana farmers in 2012, three years after the USDA approved the HTI and other states began to offer the cost-share program. Interest in and demand for the program among the state's farmers have grown since 2012, with over 170 tunnels constructed on farms since its inception. This 
represents an investment of nearly US $\$ 1.5$ million in Indiana (A. Heichelbech, personal communication, February 20, 2015). In comparison, over 10,000 farms had installed new high tunnels nationally due to the cost-share program by 2014 (Starmer, 2014). In addition to these investments from the USDA, growers have personally invested significant funds in high tunnels.

\section{Sampling, Instrumentation, and Data Collection Approach}

Since there is currently no comprehensive list of high tunnel owners in Indiana, the research team followed a convenience sampling approach, which suffices in exploratory research (Schutt, 2006). Procedures included garnering as much contact information as the Indiana NRCS office could disclose for HTI participants (143 names, with city and county of residence); using online databases (whitepages.com and county GIS platforms) to garner mailing addresses; incorporating respondents who had reported owning a high tunnel in a previous survey administered by our research group (Valliant, Farmer, Dickinson, Bruce, \& Robinson, in press); and incorporating names of our research group's personal and professional contacts who have a high tunnel. Additionally, one county extension educator hand-delivered the questionnaire (and return envelopes) to 14 growers who use high tunnels. The unsystematic selection process is a limitation to this study's results. In total, the questionnaire was distributed to 178 farmers (see the instrument in the Appendix).

While the paper instrument was the primary tool for data collection, an electronic option was also made available. Every survey included a US $\$ 5$ cash incentive to encourage participation (Dillman, Smyth, \& Christian, 2008; Singer, 2012). We followed a modified Dillman tailored-design survey method (Dillman et al., 2008) for distributing the questionnaire and collecting responses. The survey was mailed to 164 contacts. The four-phase approach included (1) a postcard announcing the survey soon to follow, (2) the survey one week later, (3) a reminder postcard to nonrespondents two weeks after that, and (4) a follow-up survey mailed to nonrespondents two weeks thereafter. We then followed up with a phone call to nonrespondents in order to evaluate the underlying issues for the nonresponse.

The survey consisted of six sections that solicited data through 38 questions. Section 1 included questions about farm location, number of high tunnels, EQIP-funded high tunnels, and descriptive information on farmers' use of their high tunnel(s). Section 2 was composed of questions concerning growers' perception of the value of the high tunnel for their farm. Section 3 queried farmers about the distribution approaches they utilized. Section 4 asked farmers about the crops they produce in their high tunnels, production issues and challenges, research needs, and common practices they employ. Section 5 asked about farm characteristics and economic issues. Section 6 queried participants for demographic information.

\section{Data Management and Analysis Approach}

We input data into an online version of the questionnaire that was built through Qualtrics software. Data were analyzed using SPSS 23.0. Descriptive and cross-tab statistics were used to calculate general results for demographic variables, farm characteristics, distribution type (direct-toconsumer or otherwise), and general mean scores related to Likert-style questions. Based on farmer responses, we created a dichotomous variable to compare farmers that (1) had only EQIP-funded high tunnels $(n=47)$ or (2) had no EQIP-funded or had a combination of EQIP- and self-funded high tunnels $(n=56)$. We used analysis of variance (ANOVA) to compare results related to the continuous variable questions (as well as the Likertstyle responses), and chi-square analysis to explore the differences in categorical variables (e.g., distribution method, gender, and education) between the two groups of farmers.

We also performed a binary logistic regression to compare the two groups (EQIP-only [1] vs. Combo/Self-funded [0]) to define key points of differentiation between the two. The six covariate variables included (1) likelihood of purchasing a future high tunnel without EQIP-funding costshare support, (2) percentage of household income earned through off-farm employment, (3) effect of the high tunnel(s) on improving farm economic stability, (4) educational attainment (bachelor's 
degree vs. no bachelor's degree), (5) their perception of the utility of high tunnels in reducing pest problems, and (6) their perception of the utility of high tunnels in improving harvest quality.

\section{Results}

Of the 178 questionnaires distributed, 118 were returned ( 6 of these were electronic). Nine were returned with insufficient addresses, four responses noted that the high tunnel was not yet erected, one person did not have a high tunnel, and one person declined to participate. One hundred and three questionnaires were deemed usable, and with an adjusted sample of 164 , we had a $62.8 \%$ response rate. The mean participant age was 36.98 , with the vast majority of respondents being the farm owner (92.2\%); $27.2 \%$ identified as female, and $48.5 \%$ of respondents had attained a bachelor's degree or higher education (see Table 1). Most respondents had an annual farm income of less than US $\$ 49,999$, with nearly $20 \%$ making less than US $\$ 5,000$ from their farms. Most (82.6\%) respondents were located in hardiness zone 5 , with $17.4 \%$ in hardiness zone 6 . The average proportion of revenue from specialty crops, when compared to total farm revenue, was $40.8 \%$ (median of $26.25 \%$ ). Table 1 provides further details on the demographic characteristics of respondents, while also differentiating and providing significance indicators for differences between those farmers who have only EQIPfunded high tunnels ("EQIP-only"; 45.6\%) and those who have only or in part self-funded high tunnels ("non-EQIP-combo"; 54.4\%).

We compared demographic and farm experience variables for the EQIP-only high tunnel users and the non-EQIP-combo group and found several statistically significant differences. The two groups demonstrate differences $(p<.05)$ for gender and age. EQIP users were more likely to be older (5.61 mean years) and female than the farmers who had purchased some or all of their high tunnels themselves. The non-EQIP-combo farmers earned more household income from the farm and had been growing in high tunnels for a longer period of time ( $p<.01)$. Last, the EQIP-only farmers were more likely to have a higher educational attainment level. The data also point to significant differences, and some marginal ones, between the two groups, with the EQIP-only farmers earning less in gross specialty crop sales, less in dollars per square foot of high tunnel production, farming fewer acres, having fewer high tunnels, and being less likely to invest their own money in future high tunnel

Table 1. Descriptive and Comparison Results of Demographic Data Overall and Between Groups

\begin{tabular}{llcc}
\hline Category & Subcategory & EQIP-only $(\boldsymbol{n}=\mathbf{4 7})$ & Non-EQIP-combo $(\boldsymbol{n}=\mathbf{5 6})$ \\
\hline Average Age** & & 40.27 mean & 34.34 mean \\
& & 41.00 median & 35.00 median \\
\hline Gender* & Female & $34.05 \%$ & $19.65 \%$ \\
& Male & $65.95 \%$ & $80.35 \%$ \\
\hline \% of household income* & Farm supplies & & 42.11 mean \\
\hline Years Farming & & 29.46 mean & 30.00 median \\
\hline Years Using High Tunnels*** & & 16.00 median & 19.69 mean \\
& & 23.89 mean & 13.50 median \\
\hline Educational Attainment** & Some high school & 25.00 median & 6.67 mean \\
& High school/GED & 3.68 mean & 5.00 median \\
\hline & Some college & 2.00 median & $19.64 \%$ \\
& Associates/Tech & $2.13 \%$ & $17.86 \%$ \\
& Bachelor's & $12.77 \%$ & $14.29 \%$ \\
& Graduate & $19.15 \%$ & $10.71 \%$ \\
\hline
\end{tabular}

Levels of statistical significance: ${ }^{*} p=.10 ; * * p=.05 ; * * * p=.010$ 
purchases (see Table 2).

We also analyzed 20 variables on the value to a farm's bottom line of producing in high tunnels (see Table 3). This included variables on farm profit, product diversification, production during the shoulder seasons (late fall and early spring), as well as pest and disease issues (see questions 13, 14, and 19 in the Appendix). Of these 20 variables, seven were found to be significantly different between the two groups. Non-EQIP-combo farmers were more likely to indicate in the survey that growing in high tunnels increased overall farm profit, overall yields, the farm's economic stability, allowed the harvesting of warm-season crops earlier in the season, improved the quality of the harvest, and reduced pest problems (vertebrate problems in particular).

Lastly, we used binary regression analysis to answer the following research question: Do farmers who obtained high tunnels only through the HTI

Table 2. Descriptive and Comparison Results of Farm Characteristic Data Overall and Between Groups

\begin{tabular}{|c|c|c|c|}
\hline Category & Subcategory & EQIP-only $(n=47)$ & Non-EQIP-combo $(n=56)$ \\
\hline \multirow[t]{7}{*}{ Farm's Gross Income } & Less than US $\$ 5,000$ & $30 \%$ & $11 \%$ \\
\hline & US $\$ 5,000-U S \$ 9,999$ & $15 \%$ & $11 \%$ \\
\hline & US\$10,000-US\$49,999 & $28 \%$ & $34 \%$ \\
\hline & US\$50,000-US\$149,999 & $13 \%$ & $30 \%$ \\
\hline & US\$150,000-US\$349,999 & $2 \%$ & $2 \%$ \\
\hline & US\$350,000-US\$499,999 & $6 \%$ & $4 \%$ \\
\hline & US $\$ 500,000+$ & $4 \%$ & $5 \%$ \\
\hline \multirow[t]{9}{*}{ Gross Specialty Crop Income ** } & Less than US $\$ 200$ & $11 \%$ & $2 \%$ \\
\hline & US\$200-US\$999 & $17 \%$ & $7 \%$ \\
\hline & US $\$ 1,000-U S \$ 9,999$ & $30 \%$ & $26 \%$ \\
\hline & US $\$ 10,000-U S \$ 24,999$ & $28 \%$ & $26 \%$ \\
\hline & US $\$ 25,000-U S \$ 49,999$ & $0 \%$ & $15 \%$ \\
\hline & US $\$ 50,000-U S \$ 99,999$ & $4 \%$ & $15 \%$ \\
\hline & US $\$ 100,000-U S \$ 249,999$ & $7 \%$ & $6 \%$ \\
\hline & US\$250,000-US\$499,999 & $0 \%$ & $4 \%$ \\
\hline & US\$500,000+ & $2 \%$ & $0 \%$ \\
\hline $\begin{array}{l}\text { Gross sales from HT per } \\
\text { square foot } a * *\end{array}$ & & $\begin{array}{l}\text { US } \$ .012 \text { mean } \\
\text { US } \$ .0007 \text { median }\end{array}$ & $\begin{array}{l}\text { US } \$ .029 \text { mean } \\
\text { US } \$ .0014 \text { median }\end{array}$ \\
\hline \multirow[t]{4}{*}{ Acres* } & $1-10$ acres (0.4-4.0 ha) & $43 \%$ & $41 \%$ \\
\hline & $11-30$ acres (4.5-12.1 ha) & $26 \%$ & $16 \%$ \\
\hline & $31-100$ acres (12.6-40.5 ha) & $9 \%$ & $29 \%$ \\
\hline & $100+$ acres $(40.6+$ ha $)$ & $23 \%$ & $14 \%$ \\
\hline \# of High Tunnels*** & & $\begin{array}{l}2.09 \text { mean } \\
2.00 \text { median }\end{array}$ & $\begin{array}{l}3.89 \text { mean } \\
3.00 \text { median }\end{array}$ \\
\hline $\begin{array}{l}\text { Likelihood of purchasing another } \\
\text { HT without EQIP funding *** }\end{array}$ & & $\begin{array}{c}2.65 \text { mean } \\
3.00 \text { median }\end{array}$ & $\begin{array}{l}3.39 \text { mean } \\
3.00 \text { median }\end{array}$ \\
\hline \multirow[t]{2}{*}{ Distribution Method } & Direct to consumer only & $57 \%$ & $66 \%$ \\
\hline & $\begin{array}{l}\text { Nondirect to consumer/Combo } \\
\text { direct/nondirect }\end{array}$ & $43 \%$ & $34 \%$ \\
\hline
\end{tabular}

${ }^{*} p<.10 ; * * p<.05 ; * * * p<.010$

${ }^{a}$ Calculation based on gross sales and gross high tunnel square footage. 
Table 3. Mean Scores (Standard Error) for Farmer Responses to Three Likert-style Batteries of Questions

\begin{tabular}{|c|c|c|}
\hline & $\begin{array}{c}\text { EQIP-only } \\
\text { Mean/Standard Error }\end{array}$ & $\begin{array}{l}\text { Non-EQIP-combo } \\
\text { Mean/Standard Error }\end{array}$ \\
\hline \multicolumn{3}{|c|}{ 1-5 likert scale ( $1=$ strongly disagree to $5=$ strongly agree) } \\
\hline 13A. Increasing overall farm profit** & $3.47(.173)$ & $3.98(.120)$ \\
\hline 13B. Adding products/diversifying & $3.20(.198)$ & $3.51(.142)$ \\
\hline 13C. Increasing fall/winter/spring production & $3.93(.167)$ & $4.09(.138)$ \\
\hline 13D. Harvesting warm season crops earlier in the season* & $3.68(.169)$ & $4.06(.125)$ \\
\hline 13E. Harvesting warm season crops later in the season & $3.75(.163)$ & $3.51(.139)$ \\
\hline $\begin{array}{l}\text { 13F. Harvesting cool season crops earlier in the coldest of } \\
\text { months }\end{array}$ & $3.30(.237)$ & $3.23(.203)$ \\
\hline 13G. Increasing cash flow in fall/winter/spring & $3.22(.208)$ & $3.50(.179)$ \\
\hline $\begin{array}{l}\text { 13H. Shifting some of the summer workload to } \\
\text { fall/winter/spring }\end{array}$ & $2.80(.200)$ & $2.83(.174)$ \\
\hline 13I. Improving quality of harvest products*** & $3.57(.166)$ & $4.17(.117)$ \\
\hline 13J. Reducing pest problems* & $3.09(.166)$ & $3.51(.167)$ \\
\hline \multicolumn{3}{|c|}{$1-6$ scale ( $1=$ strongly disagree to $6=$ strongly agree) } \\
\hline 14A. Improved farm's economic stability** & $4.50(.196)$ & $5.00(.106)$ \\
\hline 14B. Improved quality of life & $4.52(.185)$ & $4.52(.120)$ \\
\hline 14C. Significantly increased crop yields** & $4.57(.164)$ & $5.00(.104)$ \\
\hline 14D. Significantly reduced negative environmental impacts & $4.31(.179)$ & $4.56(.149)$ \\
\hline \multicolumn{3}{|c|}{$1-5$ likert scale $(1=$ extremely worse to $5=$ extremely improved $)$} \\
\hline 19A. Disease problems in the crop & $4.17(.167)$ & $4.22(.129)$ \\
\hline 19B. Insect problems in the crop & $3.80(.169)$ & $3.92(.153)$ \\
\hline 19C. Weed problems in the crop & $4.12(.136)$ & $4.24(.127)$ \\
\hline 19D. Vertebrate pest problems** & $3.55(.202)$ & $4.04(.146)$ \\
\hline 19E. Maintaining soil quality & $3.79(.189)$ & $3.67(.156)$ \\
\hline 19F. Quality of harvested product & $4.60(.118)$ & $4.75(.065)$ \\
\hline
\end{tabular}

${ }^{*} p<.10 ; * * p<.05 ; * * * p<.010$

differ from farmers who purchased some or all of their tunnels using their own funds or other non-EQIP funds? Our regression model tested the differences between the two groups of farmers (dependent variable) in relation to six variables (see Table 4). This model met statistical parameters (Hosemer Lemeshow score of $p=.629$ ) and was statistically significant $(p=.000)$. Three variables were identified as significant, and they were accurate in predicting group placement $68.4 \%$ of the time: the likelihood of purchasing another high tunnel without the EQIP cost share, the percentage of income coming from off-farm employment, and improved farm economic stability. First, as the likelihood someone would purchase a future high tunnel without the EQIP cost share increased, the chances of them being an EQIP-only high tunnel user decreased. Second, as the proportion of one's income coming from off-farm employment increased, so did the chances of them being an EQIP-only high tunnel user. Third, as respondents' scores denoting the improved farm economic stability increased, the chances of them being an EQIP-only user decreased. In summary, the EQIP-only high tunnel users depend less on farming operations for household income, are less inclined to purchase a future high tunnel out of pocket, and did not find that high tunnels improved the quality of their harvest as much as the non-EQIP-combo farmers indicated.

\section{Discussion}

Overall, the study provides evidence that at least in the state of Indiana, the HTI is enabling farmers to extend the growing season and increase the 
Table 4. Summary Statistics for Binary Stepwise Logistic Regression Model in which EQIP-only and NonEQIP-combo are Compared for Most Salient Distinguishing Variables

Independent variables retained in step 2 are listed in order of their $\operatorname{Exp}(B)$ score, with asterisks denoting significance level.

\begin{tabular}{|c|c|}
\hline & $\begin{array}{l}\text { Model } 1 \\
\text { Step } 3\end{array}$ \\
\hline Model Sign. / Step Sign. & $.000 / .015$ \\
\hline Hosemer Lemeshow & .629 \\
\hline Chi-square, Model/Step & $20.785 / 5.875$ \\
\hline-2 Log Likelihood & 116.272 \\
\hline Nagelkerke & .262 \\
\hline Percentage Accuracy & 68.4\% (EQIP-only 61.4\%; non-EQIP-combo 74.5\%) \\
\hline Variables & $B$ (S.E.; $\operatorname{Exp}[\mathrm{B}]) ; p$ \\
\hline $\begin{array}{l}\text { Likelihood of purchasing a high tunnel without NRCS funding } \\
\text { cost-share support }\end{array}$ & $-0.389(0.201 ; 677) ; 0.053 *$ \\
\hline$\%$ of household income derived from off-farm employment & $0.017(0.006 ; 1.017) ; 0.006 * * *$ \\
\hline Improved farm economic stability & $-0.601(0.256 ; 0.548) ; 0.019 * *$ \\
\hline Education (bachelors degree vs. less than bachelors) & n.s. \\
\hline Reducing pest problems & n.s \\
\hline Improved harvest quality & n.s \\
\hline Constant & $2.469(1.092 ; 11.812) ; 0.024 * *$ \\
\hline
\end{tabular}

S.E. $=$ Standard Error; n.s. $=$ not significant

$* p<.10 ; * * p<.05 ; * * * p<.010$

availability of locally grown food, based on this self-reported questionnaire and those who participated. Specifically, analysis of the results from this survey suggests three salient points. First, high tunnel users across the board (both those solely EQIP-funded and those self-funded or partially self-funded) indicate positive outcomes from growing specialty crops in high tunnels. Second, those farmers with high tunnels funded solely by EQIP earn a smaller percentage of their household income from their farms, compared to those who funded all or a portion of their own high tunnels. The most striking variable distinguishing solely EQIP-funded and self-funded or partially selffunded farmers is the economic impact of the high tunnel for farm operations. In sum, there are differences between the two groups that indicate that farmers who rely more heavily on their farms for household income and have invested more of their own resources in high tunnels have also experienced the greatest economic benefit from their tunnels. In this section, we discuss the ramifications and implications of these findings.
Overall Outcomes for High Tunnel Users

All high tunnel users in Indiana who responded to the survey (both solely EQIP funded and some/all self-funded) generally reported that growing specialty crops in high tunnels has positive effects on their farms' earnings and their own quality of life. Growers in both groups specifically indicated that growing crops in high tunnels allowed them to increase their overall farm profit and improve the economic stability of their farms. This increased economic stability is likely due to the improvements growers reported with the quality and yield of their crops. In addition, growing with high tunnels enabled them to extend the growing season into the cooler months of the year, thereby earning an income in more months of the year.

These findings are important because, as noted by Waldman and colleagues (2012) and based on our review of the literature, there has not been a systematic assessment (beyond case studies) of the economic impact of using high tunnels, or of growers' experiences with high tunnels. Existing evidence for the production benefits of growing 
specialty crops with high tunnels has been based on crop trials on research farms that may not take into account growers' experiences with integrating high tunnels into routine whole-farm management. Improving farmers' economic stability and increasing their profits is a core goal of the Know Your Farmer Know Your Food initiative, and thus an indication that the program has had a positive impact.

\section{Characteristics of EQIP-funded vs. Self-funded or Partially Self-funded High Tunnel Farmers}

Farmers in our sample who only have high tunnels funded by the EQIP program differ from those funding all or a portion of their own high tunnels in a number of respects. They are less dependent on their farm for household income, and mostly manage smaller farms. They earn less income from their specialty crops, less in dollars per square foot of high-tunnel production, and manage fewer high tunnels. They are also less likely to invest their own money in additional high tunnels in the future (see Table 2). The USDA defines farms with a gross cash farm income (GCFI) of US $\$ 10,000$ or less as noncommercial or lifestyle farms (Hoppe, MacDonald, \& Korb, 2010). Farmers in the EQIP-only funded group are typically older, likely reflecting the prevalence of owner-operators managing a lifestyle farm as a second career, hobby, or following retirement (Ahearn \& Newton, 2009). It is not surprising that the EQIP-only funded group has a higher percentage of graduate-level education, reflecting the fact that farming may not be their primary career or occupation. These findings are consistent with the results of a previous study suggesting that smallscale specialty-crop farmers who make less than US $\$ 10,000$ in annual revenue from their farm are most likely to take advantage of the HTI (FoustMeyer \& O'Rourke, 2015). Women make up more of the EQIP-only group, reflecting NSAC's preliminary analysis of national data, showing that female owner-operators have higher participation rates in EQIP programs than they do in other USDA programs (NSAC, 2014). The findings suggest that, overall, the growers who have more "skin in the game," or who have relied on their personal funds to invest in a high tunnel, are more motivated to utilize their high tunnel effectively. In general, these farms are larger with higher gross incomes and thus more capital to invest in high tunnel infrastructure. Likewise, they invest more of their labor in their high tunnel, as they are more reliant on their farm for income than the farmers in the EQIP-only group.

\section{Significance of Years of Farming Experience for Economic Success with High Tunnels}

The most striking variables distinguishing solely EQIP-funded and some or all self-funded farmers are the years one has personally farmed using a high tunnel, and the economic impact of the high tunnel for their farm operations. Those farmers who had more experience with high-tunnel production were more likely to have funded at least one of their own tunnels, as opposed to experimenting with a high tunnel for the first time through the EQIP program. This is likely because the use of high tunnels has been increasing in the U.S., and while the cost-share program was approved nationally in 2009, the state of Indiana only implemented the program in 2012. Thus some specialty-crop farmers in Indiana were using high tunnels for years before the program was implemented. As a result, the farmers who had invested in their own tunnels were able to use the EQIP program to add additional tunnels to their operation, thus expanding their high-tunnel production.

Given that the self-funded or partially selffunded farmers had gained experience with high tunnel production prior to the EQIP program, it is not surprising that they reported better economic gains from their tunnels than their less-experienced counterparts. Likewise, the EQIP-only group reported less success with improving the quality of their harvested products with high tunnels, possibly because they have less experience with high tunnel production, or perhaps because they are more likely to grow crops that do not show the same boost in quality. Because the self-funded or partially self-funded farmers rely on their farms for a greater share of their household income, they may invest more time in and attention to their high tunnels than their part-time counterparts, and therefore report more economic success with their high-tunnel production. 


\section{Policy Implications}

We expected, based on national data, that beginning farmers would be more likely to obtain EQIP funding than their more experienced counterparts. For instance, beginning farmers made up 51\% of EQIP cost-share recipients in 2013 (Huff, 2015), whereas $39.6 \%$ of our complete sample in Indiana (both EQIP-only and non-EQIP/combo) is beginning farmers. In addition, in our sample the EQIPonly group reported more years of farming experience than the non-EQIP/combo group, although the difference was not statistically significant (23.89 mean years of farming experience, compared to 19.69 years, respectively). This is more divergent when considering the median scores, with EQIPonly farmers having 25 years experience to the non-EQIP-combo farmers having 13.50 median years of experience. One possible explanation is that the cost-share program was only implemented in 2012 in Indiana, three years later than it was introduced in other states. It is possible that because the non-EQIP-combo group of farmers are generally younger and rely more heavily on their farms for income, some of them chose to invest in their own high tunnels rather than wait for the possibility that the EQIP program would be funded in Indiana.

The HTI, initially piloted under the Know Your Farmer, Know Your Food initiative, is well suited for the small-scale, diversified farms that sell their products into local food systems (Cole, n.d.; Farm News, 2009; Robillard, 2015; USDA NRCS, 2011; USDA, n.d.). Our data show that participation in the Indiana HTI reflects this programmatic focus on small farms that supply local food markets. Because high tunnels are a relatively low-cost investment that can be made up in just 1 or 2 years in many cases (Carey et al., 2009), the cost does not deter committed, commercial growers from investing in their own tunnels. Our study finds preliminary evidence that the program incentivizes small operations that may not have otherwise to experiment with a high tunnel, and that the infrastructure is relatively easy to adopt successfully. Thus the implications of our study for the HTI are that it incentivizes first-time users to adopt high tunnels and supports experienced growers in expanding their operation by adding additional tunnels to their farms. Taken together, the impact of the HTI is an increase in the volume of specialty crops grown for local food markets in the growing season and significant increases in off-season availability of fresh produce. The HTI also boosts the farm income of first-time users and especially more experienced, commercially scaled direct market farms, thus potentially boosting rural economies and local food systems.

\section{Limitations and Future Research}

Our study findings are limited by the relatively small size of the survey population (178), as the population of farmers that have utilized the HTI cost-share and invested in their own high tunnels in Indiana is relatively small overall. While our 63\% response rate is better than the norm for mailed surveys (Dillman et al., 2008), the opportunity for nonresponse bias is still very present. To understand how nonresponse bias may affect these results, we attempted to solicit an abridged dataset from nonrespondents via telephone interviews ( $22 \%$ of nonrespondents were reached). The supplementary results suggest that the $22 \%$ of nonrespondents were having (1) some kind of challenge or problem with installing their high tunnel (e.g., it had yet to be installed), (2) difficulty in fully using their high tunnel, or (3) challenges in managing their farm, in general. These patterns among nonrespondents indicate that findings may be skewed toward positive experiences implementing high tunnel production on farms. In addition, the small sample creates a potential for bias in our findings that EQIP-only farms report lower economic impact of their high tunnels, because there is a larger proportion of small farms in that group. We cannot say if farm size and EQIP participation is correlated, or test whether larger farms in the EQIP-only group reported higher scores for the question about high tunnels "increasing overall profit," because the number of these farms in the sample is too small for a robust analysis.

This sample of farmers using high tunnels in Indiana prevents us from generalizing to farmers in climates with harsher winter seasons in the upper Midwest or Northeast, or those in the western and southern regions of the U.S. In addition, we are 
not able to generalize to areas where specialty crop production is more common and economically important than it is in Indiana, such as parts of the Upper Midwest, Northeast, Pacific coast, and urban areas where high tunnels may be more prevalent. Lastly, the small sample size limits the reliability of our observations in regards to differences between the two groups (EQIP-only and combo), and thus this analysis should be taken as preliminary and exploratory.

Qualitative research is needed to explore farmers' experience with using high tunnels in more depth. For instance, interviews with this population could identify the factors that explain why some farmers report very positive experiences with their high tunnels, while others have not used them to the same capacity or have experienced challenges with high-tunnel production. In addition, we would like to further explore and understand the significance of farmers' full-time or part-time status and the percentage of income they earn from their farms for their success in using high tunnels.

\section{Conclusions}

Overall, our results suggest that the HTI is meeting its stated goals of increasing the availability of fresh produce for local food markets and is enabling farmers to extend the growing season and improve the quality of their specialty crops. The survey provides evidence that in addition to these general goals, growing under cover allows farmers to improve the yield of their crops and generally reduce pest problems. Therefore, continuing the cost-share program could potentially improve the viability of specialty crop farms over time in a number of ways. We add to the very limited research assessing the farm-level economic impacts of the High Tunnel Initiative, demonstrating that farmers have increased their financial viability by growing under cover. We also provide greater depth of understanding about the types of farmers who have depended on the HTI to provide funding for a high tunnel and those who have invested their own funds in constructing one or more high tunnels. In the big picture, the study contributes to society's understanding of a key technology that can increase the viability of mostly smallscale farms that supply local food system initiatives.

\section{References}

Ahearn, M. C., \& Newton, D. J. (2009). Beginning farmers and ranchers (Economic Information Bulletin No. 53). Washington, D.C.: USDA Economic Research Service. http://purl.umn.edu/58618

Belasco, E., Galinato, S., Marsh, T., Miles, C., \& Wallace, R. (2013). High tunnels are my crop insurance: An assessment of risk management tools for small-scale specialty crop producers. Agricultural and Resource Economics Review, 42(2), 403-418. https://doi.org/10.1017/S1068280500004445

Blomgren, T., \& Frisch, T. (2007). High tunnels: Using low-cost technology to increase yields, improve quality and extend the season. Burlington, Vermont: University of Vermont Center for Sustainable Agriculture. https://www.uvm.edu/vtvegandberry/Videos/hightunnelvideo.html

Broadway, Michael. (2009). Growing urban agriculture in North American cities: The example of Milwaukee. FOCUS on Geography, 52(3-4), 23-30. http://dx.doi.org/10.1111/j.1949-8535.2009.tb00251.x

Carey, E. E., Jett, L., Lamont, W. J., Nennich, T. T., Orzolek, M. D., \& Williams, K. A. (2009). Horticultural crop production in high tunnels in the United States: A snapshot. HortTechnology, 19, 37-43. http://horttech.ashspublications.org/

Colasanti, K. J. A., \& Hamm, M. W. (2010). Assessing the local food supply capacity of Detroit, Michigan. Journal of Agriculture, Food Systems, and Community Development, 1(2), 41-58. http://dx.doi.org/10.5304/jafscd.2010.012.002

Cole, J. (n.d.). New farmers' legacy for the land [Newsroom Features]. Retrieved from the USDA NRCS website: https://www.nrcs.usda.gov/wps/portal/nrcs/detail/national/newsroom/features/?cid=nrcseprd416282

Conner, D. S., Montri, A. D., Montri, D. N., \& Hamm, M. W. (2009). Consumer demand for local produce at extended season farmers' markets: Guiding farmer marketing strategies. Renewable Agriculture and Food Systems, 24(4), 251-259. http://dx.doi.org/10.1017/S1742170509990044 
Conner, D. S., Waldman, K. B., Montri, A. D., Hamm, M. W., \& Biernbaum, J. A. (2010). Hoophouse contributions to economic viability: Nine Michigan case studies. HortTechnology, 20, 877-884. http://horttech.ashspublications.org/

Dillman, D., Smyth, J., \& Christian, L. (2008). Internet, mail, and mixed-mode surveys: The tailored design method. Hoboken, New Jersey: John Wiley \& Sons.

Farm News. (2009, December 25). USD A launches high tunnel pilot study [News release]. Retrieved from http://www.farmnews.com/page/content.detail/id/500920/USDA-launches-high-tunnel-pilotstudy.html?nav $=5005$

Foust-Meyer, N., \& O’Rourke, M. E. (2015). High tunnels for local food systems: Subsidies, equity, and profitability. Journal of Agriculture, Food Systems, and Community Development, 5(2), 27-38. http://dx.doi.org/10.5304/jafscd.2015.052.015

Hoppe, R. A., MacDonald, J. M., \& Korb, P. (2010). Small farms in the United States: Persistence under pressure (Economic Information Bulletin No. EIB-63). Washington, D.C.: USDA Economic Research Service. Retrieved from https://www.ers.usda.gov/publications/pub-details / ?pubid $=44463$

Huff, P. (2015, April). Extending the growing season: High tunnels use and farm to school in the Upper Midwest. Institute for Agriculture and Trade Policy. Retrieved from https://www.iatp.org/documents/extending-the-growing-season

Knewtson, S. J. B., Carey, E. E., \& Kirkham, M. B. (2010). Management practices of growers using high tunnels in the Central Great Plains of the United States. HortTechnology, 20, 639-645. http://horttech.ashspublications.org/

Lamont, W. J. (2009). Overview of the use of high tunnels worldwide. HortTechnology, 19, 25-29. http://horttech.ashspublications.org/

Martinez, S., Hand, M. S., Da Pra, M., Pollack, S., Ralston, K., Smith, T.,...Newman, C. (2010). Local food systems: Concepts, impacts, and issues (Economic Research Report No. ERR-97). Washington, D.C.: USDA Economic Research Service. https://www.ers.usda.gov/publications/pub-details/?pubid $=46395$

Matts, C., Conner, D. S., Fisher, C., Tyler, S., \& Hamm, M. W. (2016). Farmer perspectives of Farm to Institution in Michigan: 2012 survey results of vegetable farmers. Renewable Agriculture and Food Systems, 31(1), 60-71. http://dx.doi.org/10.1017/S1742170514000465

Meter, K. (2012). Hoosier farmer? Emergent food systems in Indiana [Report for Indiana Department of Health]. Minneapolis, Minnesota: $\mathrm{Cr}$

ossroads Resource Center. Retrieved from http://www.crcworks.org/infood.pdf

Mount, P. (2012). Growing local food: Scale and local food systems governance. Agriculture and Human Values, 29(1), 107-121. http://dx.doi.org/10.1007/s10460-011-9331-0

National Sustainable Agriculture coalition [NSAC]. (2014a, February 5). Farm bill drill down: Beginning and socially disadvantaged farmers [Blog post]. Retrieved from http://sustainableagriculture.net/blog/2014-drilldown-bfr-sda/

NSAC. (2014b, June 27). Seasonal high tunnels support conservation and new farmers. [Blog post]. Retrieved from http://sustainableagriculture.net/blog/high-tunnel-update/

Robillard, T. (2015, December 7). High tunnel addition helps urban farmer feed Portland [Blog post]. Retrieved from http://blogs.usda.gov/2015/12/07/high-tunnel-addition-helps-urban-farmer-feed-portland/

Schutt, R. K. (2006). Investigating the social world: The process and practice of research (5 Edition). Thousand Oaks, Californaia: SAGE.

Singer, E. (2012, October). The use and effects of incentives in surveys. Presentation at the National Science Foundation, Washington, D.C. Retrieved from https://iriss.stanford.edu/sites/default/files/singer slides.pdf

Starmer, E. (2014, February 20). High tunnel initiative brings local foods to Detroit [Blog post]. Retrieved from http://blogs.usda.gov/2014/02/20/high-tunnel-initiative-brings-local-foods-to-detroit/\#more-50193

U.S. Department of Agriculture [USDA]. (n.d.). Know Your Farmer, Know Your Food Compass. Washington, D.C.: USDA. Retrieved from http://www.usda.gov/documents/KYFCompass.pdf

USDA Agricultural Marketing Service. (n.d.). What is a specialty crop? Retrieved from https://www.ams.usda.gov/services/grants/scbgp/specialty-crop

USDA National Agricultural Statistics Service [USDA NASS]. (2007). 2007 Census Volume 1, Chapter 1: State Level Data (Indiana), Tables 34, 35, and 37. Retrieved from https://www.agcensus.usda.gov/Publications/2007/Full Report/Volume 1, Chapter 1 State Level/Indiana/ 
USDA NASS. (2015). 2012 Census of Agriculture: Specialty crops. Table 8. Specialty crops acres — United States and states [Data table]. Retrieved from https://www.agcensus.usda.gov/Publications/2012/

USDA Natural Resource Conservation Service [USDA NRCS]. (2011, January 7). USD A provides update on seasonal high tunnel pilot [Press release]. Retrieved from http://www.nrcs.usda.gov/wps/portal/nrcs/detail/national/newsroom/?cid=STELPRDB1040764

USDA NRCS. (2015). FY 2015 EQIP Seasonal High Tunnel Initiative. Retrieved from http://www.nrcs.usda.gov/wps/portal/nrcs/detail/national/programs/financial/eqip/?cid=nrcs142p2 044210

Valliant, J. D., Farmer, J., Dickinson, S., Bruce, A., \& Robinson, J. (in press). It's a family thing: farm diversification and differentiation. Manuscript submitted for publication.

Waldman, K. B., Conner, D. S., Biernbaum, J. A., Hamm, M. W., \& Montri, A. D. (2012). Determinants of hoophouse profitability: A case study of 12 novice Michigan farmers. HortTechnology, 22, 215-223.

http://horttech.ashspublications.org/ 
Dear Indiana farmer,

Indiana University and Purdue University are working together to learn from Indiana's farms that have a high tunnel. We define a high tunnel as a structure covered in plastic that one can walk through upright in order to grow and maintain vegetables, fruit, flowers, herbs, etc.

If your farm has a high tunnel - even one that is unused right now - please complete this questionnaire as your insight is vital. Findings will be used to: (1) write a technical guide for high tunnels growers, (2) design and conduct high tunnels production trials at Purdue, and (3) develop outreach events to educate high tunnel operators. This survey is being conducted under the direction of Drs. James Farmer (IU School of Public Health) and Liz Maynard (Purdue College of Agriculture). Telephone: (812) 856-0969, email address: jafarmer@indiana.edu.

Every precaution will be taken to maintain the complete confidentiality of your responses and farm information. Your responses will be combined with data from roughly 400 other farms. Only aggregated numbers will be shared. You will not be identified in any reports from this project. You may stop participation at any time without loss of incentive. This questionnaire should take approximately 20 minutes to complete. If you have questions about your rights as a research participant or concerns about the study, you may contact the Indiana University Human Subjects Office at (812) 856-4242 or irb@iu.edu.

Enclosed you will find a $\$ 5$ bill as an incentive for your participation in this important study.

Sincerely,

James Farmer, Ph.D. Liz Maynard, Ph.D.

Indiana University Purdue University 


\section{Growers survev: High tunnels and Indiana farms}

\section{Section 1. Introduction}

1. In which Indiana county is your farm located?

2. How many high tunnels does your farm currently have?

3. How many total square feet of space do you have within your high tunnels?

4. How many of your farm's high tunnels were purchased using NRCS EQIP funds?

5. How many of your farm's high tunnels were purchased with the help of a loan from FSA?

6. Of all the high tunnels on your farm, how many does your farm presently use in any way?

\begin{tabular}{|l|l|l|}
\hline \multicolumn{1}{|l|}{} & $\square$ if O end survey \& mail it in \\
\hline & & $\square$ None \\
\hline$\square$ All & - & $\square$ None \\
\hline$\square$ All & $-\longrightarrow$ & $\square$ All \\
\hline$\square$ & $\square$ None (Skip to \#7) \\
\hline
\end{tabular}

7. Please indicate how your farm uses your high tunnel(s), and the approximate $\%$ of high tunnel area given to each purpose throughout the year.

\begin{tabular}{|l|r|}
\hline$\square$ A. To grow vegetables, melons or herbs & $\%$ \\
\hline$\square$ B. To grow berries or tree fruit & \\
\hline$\square$ C. To grow flowers, bedding plants or nursery crops & \\
\hline$\square$ D. For storage & \\
\hline
\end{tabular}

8. When did your farm START to grow crops in your first high tunnel?

Year:

9. If your farm STOPPED growing crops in high tunnels, when did you stop?

Not applicable: We still use our high tunnel Year:

\section{If your farm STOPPED growing crops in high tunnels, please skip to \#15 at the top of Section 4}

10. Plcasc mark the months of the ycar in which your farm is now growing more bccausc of the high tunncls. $\square$ All $\square$ None $\square$ Jan $\square$ feb $\square$ Mar $\square$ Apr $\square$ May $\square$ Jun $\square$ Jul $\square$ Aug $\square$ Sep $\square$ oct $\square$ Nov $\square$ Dec

11. Mark any months in which your farm now harvests - when it didn't used to - because of the high tunnels. $\square$ All $\square$ None $\square$ Jan $\square$ Feb $\square$ Mar $\square$ Apr $\square$ May $\square$ Jun $\square$ Jul $\square$ Aug $\square$ Sep $\square$ oct $\square$ Nov $\square$ Dec 
12. Please indicate the approximate dimensions of your high tunnels:

\begin{tabular}{|l|l|l|l|}
\hline Length & Width & Height & \# of High Tunnels this size \\
\hline & & & \\
\hline & & & \\
\hline & & & \\
\hline & & & \\
\hline & & & \\
\hline
\end{tabular}

\section{Section 2. Value of the high tunnel for your farm}

13. Please rate your high tunnel's current usefulness in each of the following ways:

\begin{tabular}{|c|c|c|c|c|}
\hline $\begin{array}{c}\text { Not at all } \\
\text { Useful }\end{array}$ & $\begin{array}{c}\text { Somewhat } \\
\text { Useful }\end{array}$ & Useful & $\begin{array}{c}\text { Very } \\
\text { Useful }\end{array}$ & $\begin{array}{c}\text { Extremely } \\
\text { Useful }\end{array}$ \\
\hline
\end{tabular}
A. Increasing overall farm profit
$\square \square$
$\square$
$\square \quad \square$
B. Adding products / diversifying

$\square \quad \square$

$\square \quad \square$
C. Increasing fall/winter/spring production

$\square \quad \square$
$\square$
$\square$
$\square$
D. Harvesting warm season crops earlier in the season

$\begin{array}{lllll}\text { E. Harvesting warm season crops later in the } & \square & \square & \square & \square \\ \text { season } & \square\end{array}$

F. Harvesting cool season crops in the coldest of months

\begin{tabular}{llcc} 
G. Increasing cash flow in fall/winter/spring & $\square$ & $\square$ & $\square$ \\
H. Shifting some of the summer workload to & $\square$ \\
fall/winter/spring & $\square$ & $\square$ & $\square$ \\
I. Improving quality of harvested products & $\square$ & $\square$ & $\square$ \\
\hline J. Reducing pest (insects, disease, weeds, & $\square$ \\
mammals, etc.) problems during production & $\square$ & $\square$ & $\square$
\end{tabular}

14. Please rate your level of agreement with the following statements: Adding a high tunnel has...

$\begin{array}{cccccc}\begin{array}{c}\text { Strongly } \\ \text { disagree }\end{array} & \begin{array}{c}\text { Disagree } \\ \text { disagree }\end{array} & \begin{array}{c}\text { Slightly } \\ \text { agree }\end{array} & \text { Agree } & \begin{array}{c}\text { Strongly } \\ \text { agree }\end{array} \\ \square & \square & \square & \square & \square & \square \\ \square & \square & \square & \square & \square & \square \\ \square & \square & \square & \square & \square & \square \\ \square & \square & \square & \square & \square & \square\end{array}$




\section{Section 3. Sales from the high tunnel}

15. How much of the products from your high tunnel (by weight) are:

None Less
$\square$
$\square$
$\square$
$\square$

A. Sold direct to final consumer

B. Sold direct to grocer / restaurant / institution

$\begin{array}{ccc}\text { half than } & \begin{array}{c}\text { More than } \\ \text { half }\end{array} & 100 \%\end{array}$

C. Sold to an aggregator / food hub / distributor

$\square$

D. Sold to a food processor

$\square$

E. Sold or donated to a food bank / similar initiative

F. Sold to Other distribution channel:

E. Distributed in Indiana

$\square$

F. Distributed out of state

$\square$

$\square$

$\square$

$\square$

$\square$

$\square$

$\square$

$\square$

16. What distribution channels / venues has your farm added in order to sell high tunnel grown products?

\section{Section 4. High tunnel production}

17. Please list your $\underline{\mathbf{S I X}}$ most financially important high tunnel crops: (for example, winter greens, lettuce, tomatoes, basil, etc.)

18. Considering your overall experience, how does yield in a high tunnel compare to yield in the field/garden? Please mark the response below. High tunnel yields:

$\begin{array}{cccccccc}\text { Decreased } & \text { Decreased } & \text { Decreased 5 } & \text { Neutral } & \text { Increased } & \text { Increased } & \text { Increased } & \text { Do not } \\ 50 \%+ & 25 \text { to } 50 \% & \text { to } 25 \% & \pm 5 \% & 5-25 \% & 25-50 \% & 50 \%+ & \text { know } \\ \square & \square & \square & \square & \square & \square & \square & \square\end{array}$

19. Generally speaking, how does production in the high tunnel compare to production in the field?

\begin{tabular}{|l|c|c|c|c|c|c|c|}
\hline & $\begin{array}{c}\text { Extremely } \\
\text { worse }\end{array}$ & $\begin{array}{c}\text { Slightly } \\
\text { worse }\end{array}$ & $\begin{array}{c}\text { No } \\
\text { change }\end{array}$ & $\begin{array}{c}\text { Slightly } \\
\text { improved }\end{array}$ & $\begin{array}{c}\text { Extremely } \\
\text { improved }\end{array}$ & $\begin{array}{c}\text { Do not } \\
\text { know }\end{array}$ & $\begin{array}{c}\text { Not } \\
\text { applicable }\end{array}$ \\
\hline A. Disease problems in the crop & $\square$ & $\square$ & $\square$ & $\square$ & $\square$ & $\square$ & $\square$ \\
\hline B. Insect problems in the crop & $\square$ & $\square$ & $\square$ & $\square$ & $\square$ & $\square$ & $\square$ \\
\hline C. Weed problems in the crop & $\square$ & $\square$ & $\square$ & $\square$ & $\square$ & $\square$ & $\square$ \\
\hline D. Vertebrate pest problems & $\square$ & $\square$ & $\square$ & $\square$ & $\square$ & $\square$ & $\square$ \\
\hline E. Maintaining soil quality & $\square$ & $\square$ & $\square$ & $\square$ & $\square$ & $\square$ & $\square$ \\
\hline F. Quality of harvested product & $\square$ & $\square$ & $\square$ & $\square$ & $\square$ & $\square$ & $\square$ \\
\hline
\end{tabular}


20. Please consider the following research topics and mark those that you would like to see research completed on. If there is a specific crop(s) you have in mind for a specific topic, please list that in the far right column.

Check if Interested

Specific Crop(s)

\section{A. Evaluating types / varieties}

B. Crop scheduling: planting dates and harvest dates

C. Harvest practices

D. Stand establishment

E. Row, bed and/or in-row spacing

F. Irrigation methods / scheduling

G. Temperature mgmt. (row covers, venting, heat storage, insulation)

H. Light (supplemental lights, types of plastic covering, etc.)

I. Soil fertility / plant nutrition

J. Insect management

K. Disease management

L. Weed management

M. Vertebrate pest management (voles, deer, birds)

$\mathrm{N}$. Low cost small tool and equipment development

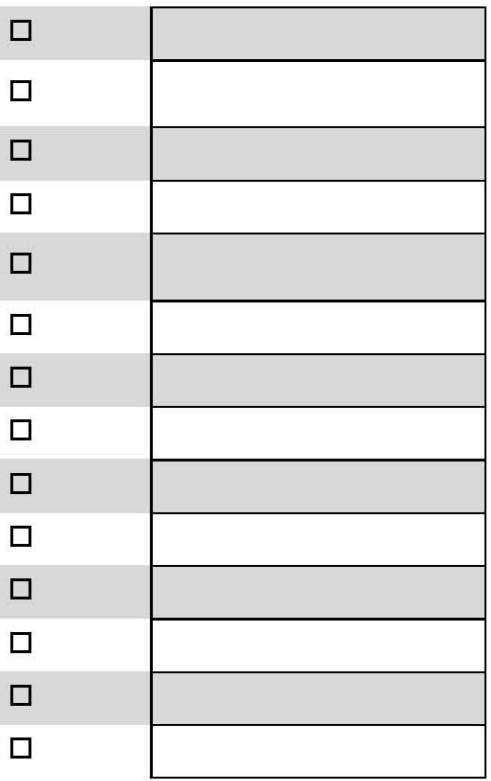

21. Which practices/items are commonly used for growing crops in high tunnels on your farm? (Check all that apply)

\begin{tabular}{|c|c|c|}
\hline \multirow{2}{*}{$\begin{array}{l}\text { A. Production } \\
\text { System }\end{array}$} & $\square$ Not organic & $\square$ Certified Organic \\
\hline & $\square$ Organic, not certified & $\square$ Other: \\
\hline \multirow{4}{*}{$\begin{array}{l}\text { B. Soil Fertility } \\
\text { and Plant } \\
\text { Nutrition }\end{array}$} & $\square$ Synthetic fertilizers & $\square$ Foliar feeding \\
\hline & $\square$ Organic fertilizers & $\square$ Fertigation \\
\hline & $\square$ Compost & $\square$ Cover crops \\
\hline & $\square$ Manure & $\square$ Other: \\
\hline \multirow{5}{*}{ C. Irrigation } & $\square$ Drip & $\square$ Well water \\
\hline & $\square$ Sprinkler & $\square$ Municipal / other public water supply \\
\hline & $\square$ Hand & $\square$ Surface water \\
\hline & $\square$ Automated on/off & $\square$ Runoff from high tunnel roof \\
\hline & $\square$ other: & \\
\hline \multirow{4}{*}{$\begin{array}{l}\text { D. Disease } \\
\text { Management }\end{array}$} & $\square$ Resistant varieties & $\square$ Fungicides (including biologicals) \\
\hline & $\square$ Environmental management & $\square$ Sanitation \\
\hline & $\square$ Crop rotation & $\square$ Cover crops \\
\hline & $\square$ Grafting & $\square$ other: \\
\hline
\end{tabular}




\begin{tabular}{|c|c|c|}
\hline \multirow{5}{*}{$\begin{array}{l}\text { E. Weed } \\
\text { Management }\end{array}$} & $\square$ Plastic mulch or weed barrier & $\square$ Hand hoeing \\
\hline & $\square$ Cover crops & $\square$ Machine cultivation \\
\hline & $\square$ Herbicides & $\square$ Solarization \\
\hline & $\square$ Hand pulling & $\square$ Flaming \\
\hline & $\square$ Organic mulch (example: straw, leaves) & $\square$ Other: \\
\hline \multirow{4}{*}{$\begin{array}{l}\text { F. Insect } \\
\text { Management }\end{array}$} & $\square$ Insecticides (including biologicals) & $\square$ Row covers \\
\hline & $\square$ Release natural enemies & $\square$ By-hand removal \\
\hline & $\square$ Providc habitat/food for naturally & $\square$ Crop rotation \\
\hline & occurring natural enemies & $\square$ other: \\
\hline \multirow{4}{*}{ H. Heat } & $\square$ Fossil fuel (example: natural gas, propane) & $\square$ Only occasional for frost/freeze protection \\
\hline & $\square$ Biomass (example: wood, corn) & $\square$ Routine, to keep air above freezing in winter \\
\hline & $\square$ Passive solar & $\square$ Routine, to keep optimum range for crop growth \\
\hline & $\square$ Geothermal & $\square$ Other: \\
\hline \multirow{4}{*}{ I. Other } & $\square$ Automated or manual venting & $\square$ Moveable \\
\hline & $\square$ Double wall plastic covering & $\square$ Single wall plastic covering \\
\hline & $\square$ Growing on tables & \\
\hline & $\square$ Geothermal & $\square$ other: \\
\hline
\end{tabular}

\section{Section 5. Your entire farm operation}

22. Please list the amount of land that you:

\begin{tabular}{|c|c|}
\hline a. Farm: & Of the land you farm, how many acres do you own? \\
\hline i. & acres \\
\hline ii. Of the land you farm, how many acres do you use to \\
raise specialty crops? acres
\end{tabular}

23. In what year did you personally begin farming, for yourself or others?

24. How many years have you personally farmed using high tunnels?

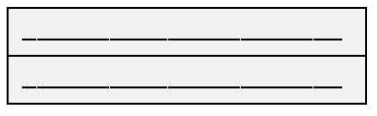

\begin{tabular}{l|lll}
$\begin{array}{l}\text { 25. In a typical year, } \\
\text { what is the value of your }\end{array}$ & $\square$ less than $\$ 5,000$ & $\square \$ 50,000$ to $\$ 149,999$ & $\square \$ 500,000$ to $\$ 999,999$ \\
farm's gross income? & $\square \$ 10,000$ to $\$ 9,999$ & $\square \$ 150,000$ to $\$ 349,999$ & $\square \$ 1$ million to $\$ 4,999,999$ \\
& $\square 49,999$ & $\square \$ 350,000$ to $\$ 499,999$ & $\square \$ 5$ million + \\
\hline $\begin{array}{l}\text { 26. In a typical year, } \\
\text { what is the value of your }\end{array}$ & $\square$ Less than $\$ 200$ & $\square \$ 10,000$ to $\$ 24,999$ & $\square \$ 100,000$ to $\$ 249,999$ \\
farm's revenue from & $\square$ 200 to $\$ 999$ & $\square \$ 25,000$ to $\$ 49,999$ & $\square \$ 250,000$ to $\$ 499,999$
\end{tabular}


27. In a typical year, what proportion of your specialty crops revenue comes from high tunnel production?

\section{$\square 0 \% \quad \square 1-25 \% \quad \square 26-50 \% \quad \square 51-75 \% \quad \square 76-99 \% \quad \square 100 \%$}

28. In a typical year, what is the dollar value of your farm's sales from high tunnels?

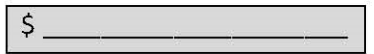

29. How much money has your farm spent out of pocket on high tunnel infrastructure?

\begin{tabular}{|c|c|c|}
\hline$\square$ Less than $\$ 999$ & $\square \$ 5,000$ to $\$ 9,999$ & $\square \$ 20,000+$ \\
\hline$\square \$ 1,000$ to $\$ 4,999$ & $\square \$ 10,000$ to $\$ 19,999$ & \\
\hline
\end{tabular}

30. How likely is your farm to purchase a $\begin{array}{cc}\text { Not at all } & \text { Not very } \\ \text { likely } & \text { likely }\end{array}$ Neutral Somewhat likely Verylikely future high tunnel without NRCS or other $\square$ $\square$

$\square$ $\square$

Section 6. Demographics \& conclusion

\begin{tabular}{|l|l|l|l|}
\hline $\begin{array}{l}\text { 31. What describes your relationship } \\
\text { to the farm? Check all that apply }\end{array}$ & $\square$ Owner or co-owner & $\square$ Employee & $\square$ Other: \\
\hline
\end{tabular}

32. In what year were you born?

33. What is your gender?

34. What percentage of your household income:

\begin{tabular}{|lc|}
\hline a. Does the farm supply? & $\%$ \\
\hline b. Comes from off-farm employment? & $\%$ \\
\hline
\end{tabular}

35. May we contact you with follow-up questions? If so, please provide your phone number. Be sure to provide the area code.

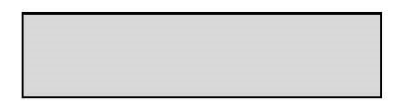

36. How much schooling have you completed?

$\begin{array}{ll}\square \text { Less than high school } & \square \text { Associate / technical degree } \\ \square \text { High school diploma / GED } & \square \text { Bachelor's degree } \\ \square \text { Some college } & \square \text { Graduate / professional degree }\end{array}$

37. Please list post-high school ag education/training/workshops that you have completed or are currently enrolled in:

38. What are the most SERIOUS CONCERNS and/or GREATEST OPPORTUNITIES you consider with your farm's high tunnel operations? If your farm DOES NOT USE your high tunnel, please share your reasons for that. 


\section{Thank you for completing this very important survey!}

Please use the stickers enclosed to seal your survey and drop it in the nearest mailbox.

J. Farmer

1025 E. $7^{\text {th }}$ St.

Bloomington, IN 47405

James R. Farmer

1025 E. $7^{\text {th }}$ St., 133

Bloomington, IN 47405 